\title{
Growth hormone regulation of DNA replication, but not insulin production, is partly mediated by somatomedin-C/insulin-like growth factor $I$ in isolated pancreatic islets from adult rats
}

\author{
I. Swenne ${ }^{1}$ and D.J.Hill ${ }^{2}$ \\ ${ }^{1}$ Department of Medical Cell Biology, Uppsala University, Sweden, and \\ ${ }^{2}$ Department of Paediatrics, Children's Hospital, University of Sheffield, UK
}

\begin{abstract}
Summary. We have investigated whether the previously demonstrated stimulatory actions of growth hormone on DNA synthesis and (pro)insulin biosynthesis and release of isolated adult rat islets of Langerhans are mediated by an autocrine release of somatomedin-C/insulin-like growth factor I (SM-C/ IGF I). In medium containing $1 \%$ fetal calf serum, the presence of $16.7 \mathrm{mmol} / 1$ glucose, or $2.7 \mathrm{mmol} / 1$ glucose supplemented with a concentrate of essential amino acids, caused a significant increase in ${ }^{3} \mathrm{H}$-thymidine incorporation and insulin release compared to $2.7 \mathrm{mmol} / \mathrm{l}$ glucose alone but no increase in SM-C/IGF I release. Further supplementation with $1 \mu \mathrm{g} / \mathrm{ml}$ growth hormone increased ${ }^{3} \mathrm{H}$-thymidine incorporation and SM-C/IGF I release within all groups, and insulin release in the $16.7 \mathrm{mmol} / 1$ glucose and $2.7 \mathrm{mmol} / 1$ plus amino acid groups. The ability of growth hormone to increase ${ }^{3} \mathrm{H}-$ thymidine incorporation in the presence of $16.7 \mathrm{mmol} / 1 \mathrm{glu}-$ cose, but not its action on insulin release, was partly inhibited by a monoclonal antibody against SM-C/IGF I (control cultures $100 \%$; growth hormone alone $261 \pm 27 \%$, mean \pm SEM; growth hormone+anti-SM-C/IGF I $179 \pm 21 \% ; p<0.05$,
\end{abstract}

$n=18$ ). Growth hormone, but not $100 \mathrm{ng} / \mathrm{ml} \mathrm{SM-C/IGF} \mathrm{I,}$ increased insulin biosynthesis assessed as immunoprecipitable ${ }^{3} \mathrm{H}$-labelled insulin by $45 \%$, but this was accompanied by a similar increase in overall protein synthesis. Similarly growth hormone, but not SM-C/IGF I caused a 75\% increase in glucose oxidation by islets. Both growth hormone and SM$\mathrm{C} / \mathrm{IGFI}$ failed to increase the cellular uptake of $\alpha$-aminoisobutyric acid or 3-O-methyl glucose over a $90 \mathrm{~min}$ period. The results suggest that while the stimulatory effect of growth hormone on islet cell insulin biosynthesis and release, glucose oxidation and general protein synthesis is probably direct, its action on B-cell replication is partly mediated by a paracrine release of SM-C/IGF I. This may provide a mechanism for increasing B-cell mass and consequently total insulin output during times of increased metabolic demands on insulin secretion.

Key words: Islets of Langerhans, B-cell replication, insulin release, insulin biosynthesis, growth hormone, insulin-like growth factor I, somatomedin C.
It is well established that growth hormone (GH) has an insulinotropic action on the pancreatic $B$ cell of a number of species. Elevation of $\mathrm{GH}$ levels in vivo stimulates insulin production concomitantly with an increased B-cell replication and development of islet hyperplasia [1-5]. Conversely, hypophysectomy in the adult rat causes a decrease in insulin biosynthesis, a poor insulin secretory response to glucose and diminished islet insulin stores [6-9]. It has also been possible to reproduce in vitro the stimulation of insulin production and islet cell replication by GH in a large number of studies (reviewed in 10). Apart from the observation that $\mathrm{GH}$ increases islet glucose metabolism [8,9] little is known, however, about the mechanisms by which $\mathrm{GH}$ exerts it anabolic and growth stimulatory actions on the adult $\mathrm{B}$ cell.

Growth-promoting actions of GH are thought to be mediated by somatomedins/insulin-like growth factors (SM/IGF) [11]. Although rat IGF II (multiplication stimulating activity, MSA) promotes B-cell replication [12], the greater effect of GH on replication and the ob- servation that this effect was additive to that of IGF II led to the suggestion that $\mathrm{GH}$ acted directly on the B cell without the mediation of SM/IGFs. Studies of the stimulation of insulin production by GH have also indicated a direct effect of the hormone on the B cell $[9$, 13]. Recently, it has become clear that SM/IGFs act predominantly as paracrine growth factors and are released by a number of different cell types [14], and that the transcription of the SM/IGF genes, especially that for somatomedin $\mathrm{C} /$ insulin-like growth factor I (SM-C/IGF I), is enhanced by GH [15]. It has also been reported that human fetal, as well as rat fetal and neonatal islet cells release SM-C/IGF I while exogenous SM-C/IGFI increases islet cell DNA replication [16-18]. Moreover, GH stimulates SM-C/IGF I release from fetal rat islets and neutralisation of the released peptide with an antibody partly inhibits the growth response elicited by GH [18]. Taken together, the findings indicate that a GH-dependent, paracrine regulation of proliferation, exists in fetal pancreatic islets. 
The present study was undertaken to establish whether a similar mechanism also operates in adult islets, and whether anabolic actions of $\mathrm{GH}$, such as stimulation of substrate utilisation and protein biosynthesis, are also mediated by SM-C/IGF I.

\section{Materials and methods}

\section{Islet isolation and culture}

Pancreatic islets were prepared by collagenase (Boehringer Mannheim, Mannheim, FRG) digestion of pancreatic glands [19] from adult male Sprague-Dawley rats (body weight 250-350 g; Anticimex, Sollentuna, Sweden). Groups of approximately 50 islets were cultured free-floating in multiwell plates (Linbro Plastics, Flow Laboratories, Irvine, UK) containing, in each well, $2 \mathrm{ml}$ RPMI 1640 tissue culture medium (Flow) supplemented with $1 \%(\mathrm{v} / \mathrm{v})$ fetal calf serum (FCS; Flow) and antibiotics (penicillin $100 \mathrm{U} / \mathrm{ml}$ and streptomycin $0.1 \mathrm{mg} / \mathrm{ml}$ ). The glucose concentration of the tissue culture medium was either 2.7 or $16.7 \mathrm{mmol} / 1$ (subsequently denoted as $2.7 \mathrm{G}$ and $16.7 \mathrm{G}$ ). In a third experimental group, the $2.7 \mathrm{G}$ medium was supplemented with $100 \mu \mathrm{l}$ amino acid concentrate per well $(100 \mathrm{X}$ Basal Eagle's Medium amino acid solution, Flow; the supplemented medium subsequently denoted as $2.7 \mathrm{GAA}$ ) thereby increasing the amino acid concentration approximately 5 -fold [20]. Some cultures were further supplemented with $100 \mathrm{ng} / \mathrm{ml}$ recombinant SM-C/IGF I. (Amersham International, Amersham, UK) or with $1 \mu \mathrm{g} / \mathrm{ml}$ human growth hormone (GH; Medical Research Council, London, UK; $1 \mu \mathrm{U}$ taken to be the equivalent of $0.5 \mathrm{ng}$ according to the 1 st International Reference preparation). In some experiments, a monoclonal antibody to SM-C/IGF I (antibody 1.20: University of North Carolina, Chapel Hill, NC, USA) was added to the culture medium at a final concentration of 1:2000 to block the effect of any SM-C/IGF I present. At this antibody dilution, the biological effects of up to at least $100 \mathrm{ng} / \mathrm{ml} \mathrm{SM}-\mathrm{C} / \mathrm{IGF} \mathrm{I}$ is blocked in a number of cultured cell types (D.J. Hill, unpublished). The preparation of this antibody and its ability to block the mitogenic response of fibroblasts and rat islets to SM-C/IGF I has been described previously [18, 21]. A monoclonal antibody to horse apoferritin served as the control. The islets were cultured in the different media for three days with a medium change after two days.

\section{Estimation of islet cell DNA replication}

To estimate the islet DNA replication methyl ${ }^{3} \mathrm{H}$-thymidine (Amersham; specific activity $5 \mathrm{Ci} / \mathrm{mmol}$ ) was added to the culture media to a concentration of $1 \mu \mathrm{Ci} / \mathrm{ml}$ for the final $24 \mathrm{~h}$. The islets were then washed briefly in non-radioactive medium and sonicated in $250 \mu \mathrm{l}$ distilled water. Duplicates, $50 \mu \mathrm{l}$ each, of the homogenates were mixed with $5 \%(\mathrm{w} / \mathrm{v})$ trichloroacetic acid (TCA) and the precipitates collected by filtration through a glass fibre $\operatorname{disc}(\mathrm{GF} / \mathrm{A}, 2.5 \mathrm{~cm}$; Labo$\mathrm{ra}$, Stockholm, Sweden). Any remaining free isotope was removed by washing with distilled water. The filters were dried and their radioactivity determined by liquid scintillation counting. Further $50 \mu \mathrm{l}$ duplicates of the homogenates were assayed for DNA content $[22,23]$, and the incorporation of labelled thymidine finally expressed as $\mathrm{dpm} / \mu \mathrm{g}$ islet DNA.

\section{Assay of insulin and $S M-C / I G F I$}

Culture medium from the last $24 \mathrm{~h}$ of culture were collected and stored frozen at $-20^{\circ} \mathrm{C}$ until assayed. Insulin was measured according to Heding [24] using crystalline mouse insulin standard. The monoclonal antibodies against SM-C/IGF I and apoferritin present in some of the medium samples did not interfere with the insulin assay. SM-C/IGF I $(100 \mathrm{ng} / \mathrm{ml})$ did not interfere with the assay.
SM-C/IGF I was dissociated from its binding proteins by acidification with hydrochloric acid and separated by reverse phase chromatography on C18 silica gel columns as previously described in detail [18]. The extracted samples were lyophilised and assayed for immunoreactive SM-C/IGF I as described elsewhere [25] using recombinant SM-C/IGF I (Amersham) standard. The cross-reactivity of rat IGF II in the assay was less than $1 \%$. Insulin at the concentrations present in the culture media showed no cross-reactivity. Culture medium supplemented with $1 \%$ FCS and incubated for $24 \mathrm{~h}$ contained less than $1 \mathrm{ng} / \mathrm{ml} \mathrm{SM-C/IGF} \mathrm{I,} \mathrm{contributing} \mathrm{less} \mathrm{than} 20 \%$ of the concentrations in culture medium conditioned by islets.

Insulin and SM-C/IGF I release into the culture medium was finally expressed as ng immunoreactive peptide/ $\mu \mathrm{g}$ islet DNA/24 h.

\section{Estimation of insulin biosynthesis}

To estimate (pro)insulin biosynthesis, groups of about 30 islets were transferred to microtiter plates (well capacity $250 \mu \mathrm{l}$; Linbro Plastics). Each well contained $100 \mu \mathrm{l}$ bicarbonate-buffered medium [26] supplemented with $2 \mathrm{mg} / \mathrm{ml}$ bovine serum albumin (fraction V; Sigma, St. Louis, Mo, USA), $100 \mu \mathrm{Ci} / \mathrm{ml} \mathrm{L}-4,5{ }^{3} \mathrm{H}$-leucine (specific activity $120 \mathrm{Ci} / \mathrm{mmol}$; Amersham), and for each group, the same glucose and hormone concentration as during the previous culture. The islets were incubated for $120 \mathrm{~min}$ at $37^{\circ} \mathrm{C}$ in a humidifed atmosphere of $5 \% \mathrm{CO}_{2}$ in air, briefly rinsed in non-radioactive buffer and sonicated in $250 \mu \mathrm{l}$ distilled water. The amount of tritiated leucine incorporated into (pro)insulin [(pro)insulin biosynthesis] was determined by an immuno-precipitation technique [27]. The amount of tritiated leucine incorporated into proteins (total protein biosynthesis) was determined by precipitation with $10 \%(\mathrm{w} / \mathrm{v})$ TCA. Further samples of the homogenates were analysed for DNA content. Tritiated leucine incorporated into immunoprecipitable (pro)insulin and TCA-precipitable proteins were finally expressed as dpm/ $\mu$ g islet DNA. Furthermore, for each individual experiment the percentage contribution of (pro)insulin biosynthesis to total protein biosynthesis was calculated.

\section{Estimation of $\alpha$-aminoisobutyric acid and 3-O-methylglucose uptake}

Determinations of the uptake of $\alpha$-aminoisobutyric acid (AIB) and 3$\mathrm{O}$-methylglucose (3-O-MG) were performed essentially according to Hellman et al. [28]. The cultured islets were pre-incubated for $60 \mathrm{~min}$ in bicarbonate buffer [29] containing $16.7 \mathrm{mmol} / 1$ glucose and, for each group, the same hormone supplement as during the previous culture. After the pre-incubation, groups of ten islets were transferred to microtiter plates containing, in each well, $250 \mu \mathrm{l}$ bicarbonate buffer with the various hormone supplements and either $16.7 \mathrm{mmol} / 1 \mathrm{H}-\mathrm{O}$ $\mathrm{MG}+10 \mu \mathrm{Ci} / \mathrm{ml}^{3} \mathrm{H}-3-\mathrm{O}-\mathrm{MG}$ (Amersham; specific activity $2.0 \mathrm{Ci}$ / $\mathrm{mmol}$ ) or $5 \mathrm{mmol} / 1 \mathrm{AIB}+1 \mu \mathrm{Ci} / \mathrm{ml}{ }^{14} \mathrm{C}$-AIB (Amersham; specific activity $59 \mathrm{mCi} / \mathrm{mmol}$ ). The islets were incubated for $5,15,45$ or $90 \mathrm{~min}$ at $37^{\circ} \mathrm{C}$ in a humidified atmosphere of $5 \% \mathrm{CO}_{2}$ in air and then carefully washed for four periods of $1 \mathrm{~min}$ each in drops of ice-cold buffer containing unlabelled 3-O-MG and AIB respectively. In separate experiments, it was demonstrated that four 1-min washing periods brought the radioactivity to stable levels which were not affected by further washings [28]. The washed islets were sonicated in distilled water, aliquots spotted on glass fibre discs which were dried and their radioactivity determined by liquid scintillation counting. Further samples of the homogenates were assayed for DNA, and the islet uptake of AIB and 3-O-MG expressed as dpm/ $\mu$ g islet DNA.

\section{Estimation of glucose oxidation}

To estimate the oxidation of glucose, duplicate groups of ten islets were incubated in $100 \mu \mathrm{l}$ bicarbonate buffered medium [29] containing $10 \mathrm{mmol} / 1$ Hepes, $16.7 \mathrm{mmol} / 1$ glucose and, for each group, the same hormone supplement as during the previous culture. To the medium was added $\mathrm{U}^{14} \mathrm{C}$-glucose (Amersham; specific activity 
$290 \mathrm{mCi} / \mathrm{mmol}$ ) to yield a final specific activity of $0.4 \mathrm{mCi} / \mathrm{mmol}$. The incubation procedure, the trapping of ${ }^{14} \mathrm{CO}_{2}$ and the calculation of results have previously been described in detail [30]. Since the various additions to the incubation medium in the course of the experiment interfered with the DNA assay, it was not possible to express the ${ }^{14} \mathrm{CO}_{2}$ production per unit DNA for each individual experiment. The DNA content was instead determined in separate groups of ten cultured islets and the average DNA content used as a common denominator (control cultures $0.36 \pm 0.03 \mu \mathrm{g}$ DNA/ 10 islets, $n=9$; cultures with $100 \mathrm{ng} / \mathrm{ml} \mathrm{SM-C} / \mathrm{IGF}$ I $0.39 \pm 0.03 \mu \mathrm{g}$ DNA $/ 10$ islets, $n=9$; cultures with $1000 \mathrm{ng} / \mathrm{ml} \mathrm{GH} 0.37 \pm 0.03 \mu \mathrm{g}$ DNA/10 islets, $n=9$ ). Islet glucose oxidation was finally expressed as pmol glucose $/ \mu \mathrm{g}$ islet DNA.

\section{Statistical analysis}

Student's two-tailed t-test for independent observations was used for statistical analyses.

\section{Results}

\section{DNA replication}

In $16.7 \mathrm{G}$ medium, the DNA replication, as determined by the incorporation of ${ }^{3} \mathrm{H}$-thymidine, was twice that observed in $2.7 \mathrm{G}$ medium (Table 1). In 2.7 GAA DNA replication was only slightly, though significantly, stimulated above the levels in $2.7 \mathrm{G}$. Addition of $\mathrm{GH}$ to the culture medium increased DNA replication irrespective of the glucose and amino acid concentration although the stimulatory effect was most marked in 16.7 G. GH-containing media with $16.7 \mathrm{G}$, but not that with $2.7 \mathrm{GAA}$, stimulated the DNA replication above the levels observed in $2.7 \mathrm{G}$.

\section{Release of insulin and SM-C/IGF I}

In $16.7 \mathrm{G}$ medium, insulin release was stimulated 7-fold compared to $2.7 \mathrm{G}$ medium while 2.7 GAA caused a $50 \%$ increase of the insulin release (Table 2). Addition of GH to the medium did not increase the insulin release in $2.7 \mathrm{G}$ but caused a $50 \%$ stimulation in both $16.7 \mathrm{G}$ and 2.7 GAA. In GH-containing media, insulin release was stimulated 9 -fold by $16.7 \mathrm{G}$ and increased $50 \%$ by 2.7 GAA compared to the values obtained in $2.7 \mathrm{G}$.

The release of SM-C/IGF I was not affected by the glucose or amino acid concentration of the medium (Table 3). Addition of GH stimulated SM-C/IGF I release by $50-80 \%$ in all groups, the stimulation being most marked in $16.7 \mathrm{G}$. In the GH-containing media, the concentration of glucose and amino acids did not affect the release of SM-C/IGF I.

\section{Effects of antibody against SM-C/IGF I on $D N A$ replication and insulin release}

When an antibody, known to block the stimulation of replication by SM-C/IGF I, was added to $16.7 \mathrm{G}$ medium neither DNA replication or insulin release was affected (Table 4). A control antibody directed against apoferritin was also without effect. SM-C/IGF I stimu-
Table 1. Effect of growth hormone on the DNA replication of cultured adult rat islets

\begin{tabular}{lllll}
\hline $\begin{array}{l}\text { Culture } \\
\text { conditions }\end{array}$ & \multicolumn{3}{l}{$\begin{array}{l}{ }^{3} \mathrm{H} \text {-thymidine incorporation } \\
\left(\mathrm{dpm} \cdot 10^{-2} \cdot \mu \mathrm{g} \text { islet DNA }\right)\end{array}$} \\
\cline { 2 - 5 } & $\begin{array}{l}\text { Control } \\
\text { cultures }\end{array}$ & & $\begin{array}{l}\text { Cultures with } \\
\text { growth hormone }\end{array}$ \\
\hline $2.7 \mathrm{mmol} / 1$ glucose & $17 \pm 1$ & $(27)$ & $28 \pm 2^{\mathrm{a}}$ & $(19)$ \\
$16.7 \mathrm{mmol} / 1$ glucose & $30 \pm 2^{\mathrm{b}}$ & $(26)$ & $74 \pm 7^{\mathrm{a}, \mathrm{b}}$ & $(16)$ \\
$\begin{array}{l}2.7 \mathrm{mmol} / 1 \text { glucose } \\
+ \text { amino acids }\end{array}$ & $22 \pm 1^{\mathrm{c}}$ & $(22)$ & $30 \pm 1^{\mathrm{a}}$ & $(14)$ \\
\hline
\end{tabular}

Islets isolated from adult rats were cultured for three days in medium containing $1 \%$ fetal calf serum and either 2.7 or $16.7 \mathrm{mmol} / 1$ glucose. In a third experimental group, medium containing $2.7 \mathrm{mmol} / 1$ glucose was supplemented with a concentrate of essential amino acids. Some cultures were, furthermore, supplemented with $1000 \mathrm{ng} / \mathrm{ml}$ human growth hormone $(\mathrm{GH})$. After two days, the media were changed and ${ }^{3} \mathrm{H}$-thymidine added. At the end of the culture, the ${ }^{3} \mathrm{H}$ thymidine incorporation into islet DNA was measured and expressed on the basis of the DNA content of the islets. Results are given as means $\pm S E M$ for the number of observations indicated. Significance of difference versus control cultures (no hormone) but the same glucose and amino acid concentration: ${ }^{a} p<0.001$; significance of difference versus cultures with $2.7 \mathrm{mmol} / 1$ glucose and the same hormone supplement, ${ }^{\mathrm{b}} p<0.001,{ }^{\mathrm{c}} p<0.01$

Table 2. Effects of growth hormone on the insulin release of cultured adult rat islets

\begin{tabular}{lllll}
\hline $\begin{array}{l}\text { Culture } \\
\text { conditions }\end{array}$ & \multicolumn{3}{l}{$\begin{array}{l}\text { Insulin release } \\
\text { (ng insulin } \mu \mu \mathrm{g} \text { islet DNA.24 h) }\end{array}$} \\
\cline { 2 - 5 } & $\begin{array}{l}\text { Control } n \\
\text { cultures }\end{array}$ & & $\begin{array}{l}\text { Cultures with } \\
\text { growth hormone }\end{array}$ & $n$ \\
\hline $2.7 \mathrm{mmol} / 1$ glucose & $138 \pm 9$ & $(27)$ & $168 \pm 17$ & $(19)$ \\
$16.7 \mathrm{mmol} / 1$ glucose & $916 \pm 60^{\mathrm{a}}$ & $(21)$ & $1468 \pm 170^{\mathrm{a}, \mathrm{b}}$ & $(14)$ \\
$\begin{array}{l}2.7 \mathrm{mmol} / 1 \text { glucose } \\
+ \text { amino acids }\end{array}$ & $212 \pm 20^{\mathrm{a}}$ & $(24)$ & $304 \pm 31^{\mathrm{c}, \mathrm{d}}$ & $(14)$ \\
\hline
\end{tabular}

Insulin release into the culture medium was measured during the last $24 \mathrm{~h}$ of a three day culture period (see legend to Table 1) and expressed on the basis of the DNA content of the islets. Results are given as means $\pm S E M$ for the number of observations indicated. Significance of difference versus control cultures (no hormone) but the same glucose and amino acid concentration: ${ }^{b} p<0.001,{ }^{c} p<0.05$; significance of difference versus cultures with $2.7 \mathrm{mmol} / 1$ glucose but the same hormone supplement: ${ }^{\mathrm{a}} p<0.001{ }^{\mathrm{d}} p<0.05$

Table 3. Effects of growth hormone on the release of somatomedin$\mathrm{C} /$ insulin-like growth factor I of cultured adult rat islets

\begin{tabular}{|c|c|c|c|c|}
\hline \multirow[t]{2}{*}{$\begin{array}{l}\text { Culture } \\
\text { conditions }\end{array}$} & \multicolumn{4}{|c|}{$\begin{array}{l}\text { SM-C/IGF I release } \\
\text { (ng peptide } \cdot \mu \mathrm{g} \text { islet DNA } \cdot 24 \mathrm{~h} \text { ) }\end{array}$} \\
\hline & $\begin{array}{l}\text { Control } \\
\text { cultures }\end{array}$ & $n$ & $\begin{array}{l}\text { Cultures with } \\
\text { growth hormone }\end{array}$ & $n$ \\
\hline $2.7 \mathrm{mmol} / 1 \mathrm{glucose}$ & $27 \pm 2$ & $(29)$ & $41 \pm 6^{a}$ & (19) \\
\hline $16.7 \mathrm{mmol} / 1$ glucose & $27 \pm 3$ & (28) & $49 \pm 7^{b}$ & $(20)$ \\
\hline $\begin{array}{l}2.7 \mathrm{mmol} / 1 \text { glucose } \\
+ \text { amino acids }\end{array}$ & $26 \pm 3$ & (19) & $43 \pm 9^{\mathrm{a}}$ & (14) \\
\hline
\end{tabular}

Somatomedin $\mathrm{C} /$ insulin-like growth factor I (SM-C/IGF I) release into the culture medium was measured during the last $24 \mathrm{~h}$ of a three day culture period (see legend to Table 1) and expressed on the basis of the DNA content of the islets. Results are given as means \pm SEM for the number of observations indicated. Significance of difference versus control cultures (no hormone) but the same glucose and amino acid concentrations: ${ }^{\mathrm{a}} p<0.05,{ }^{\mathrm{b}} p<0.01$ 
Table 4. Effects of an antibody to somatomedin-C/insulin-like growth factor I on the DNA replication and insulin release of cultured adult rat islets

\begin{tabular}{lllll}
\hline Medium supplement & $\begin{array}{l}{ }^{3} \text { H-thymidine } \\
\text { incorporation }\end{array}$ & $n$ & $\begin{array}{l}\text { Insulin } \\
\text { release }\end{array}$ & $n$ \\
\hline No addition & 100 & & 100 & \\
Anti-somatomedin & $103 \pm 6$ & $(16)$ & $105 \pm 7$ & $(11)$ \\
Anti-apoferritin & $101 \pm 8$ & $(16)$ & $105 \pm 8$ & $(11)$ \\
SM-C/IGF I & $171 \pm 23^{\mathrm{a}, \mathrm{d}}$ & $(7)$ & $115 \pm 13$ & $(7)$ \\
SM-C/IGF I+ & $104 \pm 14$ & $(7)$ & $109 \pm 14$ & $(7)$ \\
anti-somatomedin & & & & \\
SM-C/IGF I+ & $161 \pm 17^{\mathrm{a}, \mathrm{d}}$ & $(7)$ & $118 \pm 16$ & $(7)$ \\
anti-apoferritin & $261 \pm 27^{\mathrm{c}}$ & $(18)$ & $180 \pm 14^{\mathrm{c}}$ & $(14)$ \\
GH & $179 \pm 21^{\mathrm{b}}$ & $(18)$ & $173 \pm 17^{\mathrm{c}}$ & $(14)$ \\
GH + anti-somatomedin & & & & \\
GH + anti-apoferritin & $280 \pm 41^{\mathrm{b}}$ & $(18)$ & $188 \pm 15^{\mathrm{c}}$ & $(14)$ \\
\hline
\end{tabular}

Islets isolated from adult rats were cultured for three days in medium containing $16.7 \mathrm{mmol} / \mathrm{l}$ glucose and $1 \%$ fetal calf serum. Some cultures were also supplemented with $100 \mathrm{ng} / \mathrm{ml}$ somatomedin $\mathrm{C} / \mathrm{in}$ sulin-like growth factor I (SM-C/IGF I) or $1000 \mathrm{ng} / \mathrm{ml}$ human growth hormone (GH). To block the effects of any somatomedin C/insulin-like growth factor I (SM-C/IGF I) present in the media, a monoclonal antibody to SM-C/IGF I was added to some of the cultures. Antibody to horse apoferritin served as control. After two days, the media were changed and ${ }^{3} \mathrm{H}$-thymidine added. At the end of the culture period, the ${ }^{3} \mathrm{H}$-thymidine incorporation into islet DNA and the insulin release into the culture medium were measured and expressed on the basis of the DNA content of the islets. Results are given as means \pm SEM for the number of observations indicated and expressed as percentages of the ${ }^{3} \mathrm{H}$-thymidine incorporation and insulin secretion obtained, in each experiment, in islets cultured without $\mathrm{GH}$ and antibodies. Significance of difference versus control cultures (no hormone or antibody): ${ }^{\mathrm{a}} p<0.05 ;{ }^{\mathrm{b}} p<0.01 ;{ }^{\mathrm{c}} p<0.001$. Significance of difference versus cultures with anti-somatomedin antibody: d $p<0.05$

Table 5. Effects of growth hormone and somatomedin-C/insulin-like growth factor I on the insulin biosynthesis of cultured adult rat islets

\begin{tabular}{lclcl}
\hline $\begin{array}{l}\text { Medium } \\
\text { supplement }\end{array}$ & $n$ & $\begin{array}{l}\text { (Pro)insulin } \\
\text { biosynthesis } \\
\left(\text { dpm } \cdot 10^{-5} .\right. \\
\mu \mathrm{g} \text { islet DNA) }\end{array}$ & $\begin{array}{l}\text { Total protein } \\
\text { biosynthesis } \\
\left(\text { dpm } \cdot 10^{-5} .\right. \\
\mu g \text { islet DNA) }\end{array}$ & $\%$ \\
\hline $\begin{array}{l}\text { No addition } \\
100 \mathrm{ng} / \mathrm{ml}\end{array}$ & 19 & $191 \pm 15$ & $775 \pm 67$ & $25.4 \pm 1.1$ \\
$\mathrm{SM}-\mathrm{C} / \mathrm{IGF}$ I & 21 & $181 \pm 12$ & $643 \pm 44$ & $29.2 \pm 1.7$ \\
$1000 \mathrm{ng} / \mathrm{ml} \mathrm{GH}$ & 23 & $276 \pm 24^{\mathrm{a}}$ & $1110 \pm 101^{\mathrm{b}}$ & $25.3 \pm 0.9$ \\
\hline
\end{tabular}

Islets isolated from adult rats were cultured for three days in medium containing $16.7 \mathrm{mmol} / 1$ glucose, $1 \%$ fetal calf serum and in some cases supplemented with either $100 \mathrm{ng} / \mathrm{ml}$ somatomedin $\mathrm{C} /$ insulinlike growth factor I (SM-C/IGF I) or $1000 \mathrm{ng} / \mathrm{ml}$ human growth hormone $(\mathrm{GH})$. At the end of the culture period, the islets were incubated for two $\mathrm{h}$ with ${ }^{3} \mathrm{H}$-leucine. The amount of radioactivity incorporated into (pro)insulin ([pro]insulin biosynthesis) was determined by immuno-precipitation with an insulin antibody and the total amount of radioactivity incorporated into islet proteins (total protein biosynthesis) by precipitation with trichloroactic acid. The results are expressed on the basis of the DNA content of the islets and given as means $\pm S E M$ for the number of observations indicated. Furthermore, for each individual experiment the percentage contribution of (pro)insulin biosynthesis to total protein biosynthesis was calculated. Significance of difference versus control cultures (no hormone): ${ }^{\mathrm{a}} p<0.01$, ${ }^{\mathrm{b}} p<0.05$
Table 6. Effect of growth hormone and somatomedin-C/insulin-like growth factor I on the glucose oxidation of cultured adult rat islets

\begin{tabular}{|c|c|c|c|}
\hline $\begin{array}{l}\text { Medium } \\
\text { supplement }\end{array}$ & $n$ & $\begin{array}{l}\text { Glucose oxidation } \\
\text { (pmol } 10 \text { islets. } \\
90 \mathrm{~min} \text { ) }\end{array}$ & $\begin{array}{l}\text { (pmol } \cdot \mu \mathrm{g} \text { islet } \\
\text { DNA } 90 \mathrm{~min} \text { ) }\end{array}$ \\
\hline No addition & 10 & $661 \pm 80$ & $1848 \pm 223$ \\
\hline $\begin{array}{l}100 \mathrm{ng} / \mathrm{ml} \\
\mathrm{SM}-\mathrm{C} / \mathrm{IGF} \mathrm{I}\end{array}$ & 12 & $727 \pm 60$ & $1854 \pm 153$ \\
\hline $1000 \mathrm{ng} / \mathrm{ml} \mathrm{GH}$ & 12 & $1160 \pm 154^{\mathrm{a}}$ & $3152 \pm 418^{a}$ \\
\hline
\end{tabular}

Islets isolated from adult rats were cultured for three days in medium containing $16.7 \mathrm{mmol} / 1$ glucose, $1 \%$ fetal calf serum and in some cases supplemented with $1010 \mathrm{ng} / \mathrm{ml}$ somatomedin $\mathrm{C} /$ insulin-like growth factor I (SM-C/IGF I) or $1000 \mathrm{ng} / \mathrm{ml}$ growth hormone (GH). At the end of the culture period the islets were incubated for $90 \mathrm{~min}$ with $\mathrm{U}-{ }^{14} \mathrm{C}$-glucose, the amount of ${ }^{14} \mathrm{CO}_{2}$ produced measured and used as an index of glucose oxidation. The DNA content was measured in separate groups of ten islets and their mean DNA content used as a common denominator. Values are given as means \pm SEM for the number of observations indicated. Significance of difference versus control cultures (no hormone): ${ }^{\mathrm{a}} p<0.05$

lated DNA replication and this effect could be abolished by the somatomedin antibody but not by the control antibody. However, SM-C/IGF I did not stimulate insulin release. GH stimulated both DNA replication and insulin release as indicated above. The stimulatory effect of GH on DNA replication could partly be blocked by the antibody against SM-C/IGF I but not by the control antibody. Both antibodies failed to affect GH-stimulated insulin release.

\section{(Pro)insulin biosynthesis, glucose oxidation and uptake of glucose and amino acid analogues}

After culture in $16.7 \mathrm{G}$, a considerable (pro)insulin biosynthesis, as determined by the incorporation of ${ }^{3} \mathrm{H}-\mathrm{leu}$ cine into immunoprecipitable insulin, and contributing $25 \%$ to the total protein biosynthesis could be demonstrated (Table 5). Addition of SM-C/IGF I to the culture medium failed to increase (pro)insulin and total protein biosynthesis. On the other hand, culture with GH stimulated both (pro)insulin and total protein biosynthesis by about $50 \%$. The percentage contribution of insulin biosynthesis to total protein biosynthesis thus remained unchanged.

By the same token, islet glucose oxidation was stimulated by the addition of $\mathrm{GH}$ to $16.7 \mathrm{G}$ medium but not by the addition of SM-C/IGF I (Table 6).

The cellular uptake of 3-O-MG and AIB was similar after culture in $16.7 \mathrm{G}$ medium without hormones or with either GH or SM-C/IGF I added (Fig.1). Thus, no differences could be detected either in the initial rates of uptake or in the steady state levels.

\section{Discussion}

Islets isolated from adult rats contain only a small fraction of proliferating cells but have, nevertheless, proven useful for the study of islet cell replication [31]. The use of 


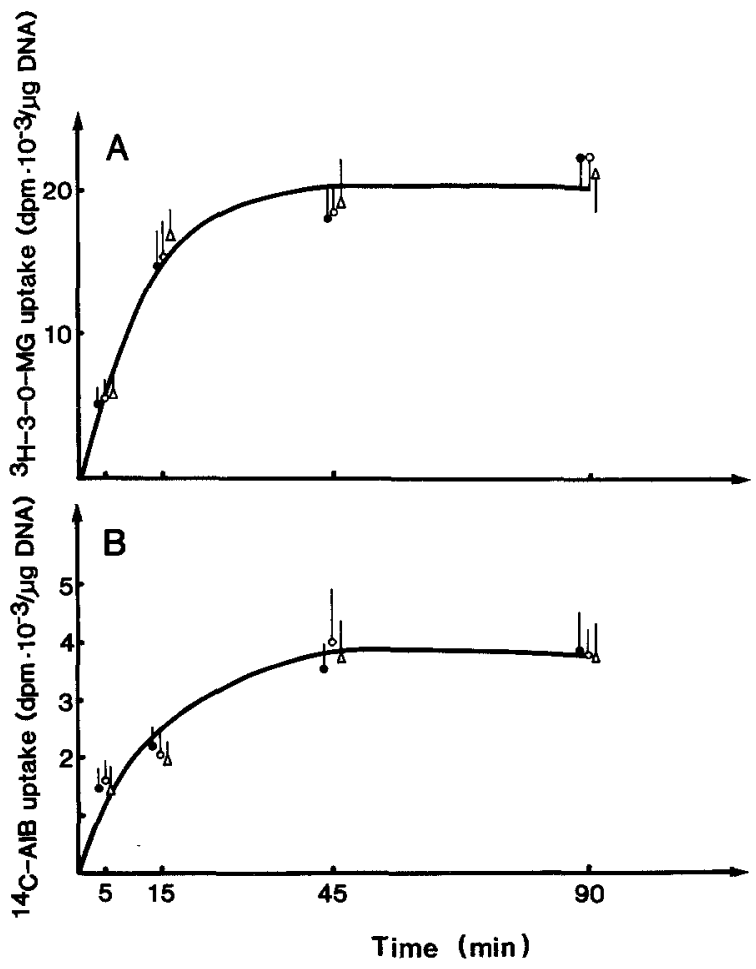

Fig. $1 \mathrm{~A}$ and B. Effects of growth hormone (GH) and somatomedin C/insulin-like growth factor I (SM-C/IGF I) on the uptake of $\alpha$-aminoisobutyric acid (AIB) and 3-O-methylglucose (3-O-MG) of cultured adult rat islets. Islets isolated from adult rats were cultured for three days in medium containing $16.7 \mathrm{mmol} / 1$ glucose, $1 \% \mathrm{FCS}$ and in some cases $100 \mathrm{ng} / \mathrm{ml} \mathrm{SM-C/IGF} \mathrm{I} \mathrm{or} 1000 \mathrm{ng} / \mathrm{ml} \mathrm{GH}$. Following a pre-incubation, the islets were incubated in a bicarbonate buffered medium containing the same hormone supplement as during the previous culture and either $16.7 \mathrm{mmol} / \mathrm{1}^{3} \mathrm{H}-3-\mathrm{O}-\mathrm{MG}$ or $5 \mathrm{mmol} / \mathrm{1}$ ${ }^{14} \mathrm{C}$-AIB. The incubations were stopped at the time points indicated and any extracellular radiollabel was removed by washing for four periods of $1 \mathrm{~min}$ in ice-cold buffer. The uptake of isotope is expressed on the basis of the DNA content of the islets and given as means \pm SEM for 6-9 observations. The symbols designate control cultures $(\bullet)$, cultures with SM-C/IGF I $(\triangle)$, and cultures with $\mathrm{GH}(\mathrm{O})$

${ }^{3} \mathrm{H}$-thymidine as an index of islet cell replication and multiplication is well documented, and it is established that measurements of ${ }^{3} \mathrm{H}$-thymidine incorporation reflects cell multiplication [20,32]. Furthermore, since cultured adult rat islets contain $>85 \% \mathrm{~B}$ cells (Swenne, unpublished), it has been assumed that the results reflect B-cell function. The concentration of FCS used in the present study was chosen for its ability to maintain the responsiveness of islet cell replication and hormone production to nutrients and hormones in vitro without interfering with the analysis of SM-C/IGF I in the culture medium [18]. The high concentration of $\mathrm{GH}(1 \mu \mathrm{g} / \mathrm{ml})$ used is almost a hundred-fold in excess of the average serum concentration of $\mathrm{GH}$ in adult rats. However, the rapid oscillations of $\mathrm{GH}$ secretion in the rat result in frequent episodes where GH concentrations of several hundred $\mathrm{ng} / \mathrm{ml}$ can be attained throughout the day [33-35]. Since it may be that not only the concentration of GH but also the number and rate of increment of the secretory bursts determine the effects of GH on peripheral tissues, it is difficult to evaluate the physiological significance of a continuous stimulation by $1 \mu \mathrm{g} / \mathrm{ml} \mathrm{GH}$. Nevertheless, this concentration gives clear-cut effects on the different parameters of islet function $[12,18,36]$ and does show the potential pathways which could operate.

The present investigation demonstrates that SM-C/ IGF $I$ is secreted by adult rat islets in tissue culture, thereby extending similar findings in fetal and neonatal islet tissue $[17,18]$ and confirming the presence of SM-C/IGF I in adult rat islets [37]. At variance with our previous study with fetal islets [18], GH stimulated SM-C/IGF I release from adult islets also in the presence of a low glucose concentration. Moreover, the absolute levels of SM-C/IGF I secretion were higher in adult islets. This would indicate a higher capacity for protein synthesis and secretion in adult islet cells, a notion supported also by higher levels of insulin secretion compared to fetal islets $[18,20]$. As in other adult rat tissues, the secretion of SM-C/IGF I was stimulated by $\mathrm{GH}$ and also accompanied by an increase in islet cell replication. These findings could suggest that some of the GH effects on DNA replication are mediated by a paracrine mechanism. The islet cells could then be stimulated by $\mathrm{GH}$ to produce somatomedins which in turn could stimulate cell proliferation within the islet. This notion is supported by the observation that the growth stimulation by GH could be partly inhibited by an antibody known to inhibit growth stimulation of islets by SM-C/IGF I [18]. Since IGF II expression declines to almost undetectable levels in adult rat tissues, including the pancreas [38], SM-C/IGF I is likely to be the only $\mathrm{SM} / \mathrm{IGF}$ expressed and thus the only one to be considered as a possible mediator of $\mathrm{GH}$ action. We have previously demonstrated that serum stimulation of islet cell DNA replication is not inhibited by the antibody [18], and it thus appears that this serum effect is mediated by factors other than SM-C/IGF I. The antibody, however, also failed to inhibit DNA replication under basal conditions in the absence of $\mathrm{GH}$ despite the release of significant amounts of SM-C/IGF I. This is at variance with results obtained with monolayer cultures of other cell types [21] and remains, hitherto, unexplained.

In this context, it should be noted that the antibody against SM-C/IGF I did not completely abolish the growth response to GH. The GH-stimulated SM-C/ IGF I production was approximately similar in the different glucose and amino acid concentrations despite widely different rates of ${ }^{3} \mathrm{H}$-thymidine incorporation. It appears, therefore, that nutrient stimulation and part of the GH stimulation of islet cell replication is direct and not mediated by production and/or release of SM/IGFs. The stimulation of replication by GH was greatest in the presence of a high glucose concentration, an observation which lends support to the view that nutrients, and among these, notably glucose, are the major regulators of islet cell replication while hormonal stimuli act by modulating the response to nutrients [10]. 
In contrast to the effect on islet cell replication, SM-C/IGF I did not stimulate insulin release into the culture medium. Furthermore, GH-stimulated insulin secretion could not be blocked by the antibody against SM-C/IGF I. The absence of somatomedin mediation of the GH effects on insulin production is further supported by the observation that GH, but not SM-C/ IGFI, stimulated insulin biosynthesis. It is notable that GH stimulated insulin and total protein biosynthesis to the same extent, i.e. there was not a preferential stimulation of insulin production. This observation may reflect the general stimulation of nutrient uptake and metabolism by GH seen in a number of tissues [39]. However, while GH enhanced glucose oxidation by islets we could not demonstrate GH-dependent non-metabolisable glucose and amino acid analogue transport. Substrate transport across the B-cell membrane is, however, very efficient and not rate-limiting for substrate oxidation, insulin biosynthesis and insulin secretion [28, 40-43]. A stimulatory effect of $\mathrm{GH}$ on substrate uptake at the level of the cell membrane is, therefore, not a prerequisite for an increased substrate oxidation. Since stimulation of insulin biosynthesis and secretion by glucose is closely linked to glucose oxidation [42], it seems likely that $\mathrm{GH}$ exerts its effects on insulin production by increasing metabolic fluxes in the B cell. It is, however, notable that GH does not have immediate effects but requires several hours before a stimulation of insulin production can be demonstrated [13]. This suggests that induction of protein synthesis is necessary before the stimulation of insulin production becomes evident [9].

Since SM-C/IGF I mediated part of the growth stimulatory effect of GH it would be expected that the former peptide could mimic the anabolic effects of $\mathrm{GH}$. SM-C/IGF I, however, failed to stimulate substrate uptake, glucose oxidation and total protein biosynthesis of the islets despite a stimulatory effect on DNA replication. In view of the very small proportion of cells taking part in proliferation in adult islets [31] and since it is likely that proliferation is not possible without an increase in substrate utilisation and protein biosynthesis, it is possible that such anabolic effects were below levels of detection given the far greater proportion of nonproliferating cells. The findings would then suggest that only the cell fraction capable of proliferation responds to SM-C/IGFI and the possibility thus arises of identifying this population by the presence of SM-C/ IGF I receptors.

Our results demonstrate a dual action of $\mathrm{GH}$ on islet cell function. First, there is a direct action on insulin production and islet cell replication. This direct effect of $\mathrm{GH}$ is closely associated with substrate metabolism and may represent a mechanism for rapid adaptation to the hormonal stimulation and would also counteract the general diabetogenic effect of $\mathrm{GH}$ in the organism [39]. Considering that several hours are needed before GH exerts its stimulatory effect on insulin production [44], it seems likely that an increased expression of the insulin gene is involved in the process [45]. Second, GH stimulates the production of SM-C/IGF I in the islets which, via a paracrine mechanism, stimulates islet cell replication but not insulin production in the individual $B$ cells. It is conceivable that this mechanism could increase the insulin output in the long-term by increasing the total B-cell mass in response to persistent demands on insulin secretion. To what extent the two different processes add to an increased insulin production under physiological conditions in vivo remains, however, to be clarified.

Our investigation thus demonstrates that in the adult endocrine pancreas an intrinsic, or paracrine, control of proliferation exists, namely the release of SM-C/ IGFI. It is regulated by $\mathrm{GH}$ and possibly by other polypeptide hormones such as placental lactogens which also stimulate insulin production and islet cell replication [36, 46]. During periods of increased metabolic stress, like during the pubertal growth spurt or during pregnancy, this mechanism may be necessary to increase B-cell mass in association with increasing demands on insulin output. Failure to do so and an inadequately low total B-cell mass may lead to a blunted insulin secretory response to glucose [47] and a lowered total insulin output which in turn pre-disposes for diabetes [10].

Acknowledgements. The authors are grateful to Professor C.Hellerström for discussions during the preparation of this manuscript. The skilful technical assistance of I. Hallgren and J. Milnes is gratefully acknowledged. The polyclonal antibody against SM-C/IGF I used in the radioimmunoassay and the monoclonal antibody used in the culture experiments were kindly provided by Drs. L.E. Underwood, J.J. Van Wyk and A.J. D'Ercole, University of North Carolina, Chapel Hill, NC, USA. This work was supported by the Swedish Diabetes Association, the Expressen Prenatal Research Foundation, the Novo Company, the Juvenile Diabetes Foundation, the Nordisk Grant for the Study of Growth, the Novo Company, Birthright, and the Swedish Medical Research Council (12X-109, 12P-6494).

\section{References}

1. Cicchitti LF (1964) Growth hormone and mitoses in the islets of Langerhans of the rat. Acta Physiol Lat Am 14: 324-326

2. Martin JM, Åkerblom HK, Garay G (1968) Insulin secretion in rats with elevated levels of circulating growth hormone due to MtT-W15 tumor. Diabetes 17:661-667

3. Peak GT, McKeel DW, Mariz IK, Jarett L, Daughaday WH (1969) Insulin storage and release in rats bearing growth hormone secreting tumors. Diabetes 18: 619-624

4. Pierlussi J, Pierlussi R, Ashcroft SJH (1980) Effects of growth hormone on insulin release in the rat. Diabetologia 19: 391-396

5. Parsons JA, Hartfel MA, Hegre OD, McEvoy RC (1983) Effects of MtTW15 mammasomatotropic tumors on pancreatic islet hormones. Diabetes 32: 67-74

6. Malaisse WJ, Malaisse-Lagae F, King S, Wright PH (1968) Effect of growth hormone on insulin secretion. Am J Physiol 215: $423-428$

7. Schatz H, Abdel Rahman Y, Hinz M, Fehm HL, Nierle C, Pfeiffer EF (1973) Hypophysis and function of pancreatic islets. I. The influence of hypophysectomy on insulin secretion and biosynthesis of proinsulin and insulin in isolated pancreatic islets of rats. Diabetologia 9: 135-139 
8. Parman AÜ (1975) Effects of hypophysectomy and short-term growth hormone replacement on insulin release from and glucose metabolism in isolated rat islets of Langerhans. J Endocrinol 67: 1-17

9. Pierlussi J, Pierlussi R, Ashcroft SJH (1982) Effects of hypophysectomy and growth hormone on cultured islets of Langerhans of the rat. Diabetologia 22: 134-137

10. Hellerström C, Swenne I (1985) Growth pattern of pancreatic islets in animals. In: Volk BW, Arquilla ER (eds) The diabetic pancreas. Plenum, New York, p 53-79

11. Van Wyk JJ (1984) The somatomedins: biological actions and physiological control mechanisms. In: Li CH (ed) Hormonal proteins and peptides, vol 12. Academic Press, New York, pp 81-96

12. Rabinovitch A, Quigley C, Rechler MM (1983) Growth hormone stimulates islet B-cell replication in neonatal rat pancreatic monolayer cultures. Diabetes 32: 307-312

13. Whittaker PJ, Taylor KW (1980) Direct effects of rat growth hormone on rat islet of Langerhans in tissue culture. Diabetologia 18: 323-328

14. Milner RDG, Hill DJ (1987) Interaction between endocrine and paracrine peptides in prenatal growth control. Eur J Paediatr 146: $113-122$

15. Murphy LJ, Bell GI, Friesen HG (1987) Tissue distribution of insulin-like growth factor I and II messenger ribonucleic acid in the adult rat. Endocrinology 120: 1279-1282

16. Hill DJ, Frazer A, Swenne I, Wirdnam PK, Milner RDG (1987) Somatomedin-C in human fetal pancreas. Cellular localization and release during culture. Diabetes $36: 465-471$

17. Romanus JA, Terrel JE, Yang YWH, Nissley SP, Rechler MM (1986) Insulin-like growth factor carrier proteins in neonatal and adult rat serum are immunologically different: demonstration using a new radioimmunoassay for the carrier protein from BRL3 A rat liver cells. Endocrinology 118: 1743-1758

18. Swenne I, Hill DJ, Strain AJ, Milner RDG (1987) Growth hormone regulation of somatomedin $\mathrm{C}$ /insulin-like growth factor I production and DNA replication in fetal rat islets in tissue culture. Diabetes 36: 288-294

19. Howell SL, Taylor KW (1968) Potassium ions and the secretion of insulin by islets of Langerhans incubated in vitro. Biochem $\mathrm{J} 108$ : $17-24$

20. Swenne I, Bone AJ, Howell SL, Hellerström C (1980) Effects of glucose and amino acids on the biosynthesis of DNA and insulin in fetal rat islets maintained in tissue culture. Diabetes 29:686-692

21. Russel WE, Van Wyk JJ, Pledger WJ (1984) Inhibition of the mitogenic effects of plasma by a monoclonal antibody to somatomedin C. Proc Natl Acad Sci USA 81: 2389-2392

22. Kissane JM, Robins E (1958) The fluorometric measurement of deoxyribonucleic acid in animal tissues with special reference to the central nervous system. J Biol Chem 233: 184-188

23. Hinegardner RT (1971) An improved fluorometric assay for DNA. Anal Biochem 39: 197-201

24. Heding L (1972) Determination of total serum insulin (IRI) in insulin-treated diabetic patients. Diabetologia $8: 260-266$

25. Hill DJ, Crace CJ, Fowler L, Holder AT, Milner RDG (1984) Cultured fetal rat myoblasts release peptide growth factors which are immunologically and biologically similar to somatomedin. J Cell Physiol 119: 349-358

26. Gey GO, Gey MK (1936) The maintenance of human normal cells and tumor cells in continous culture. I. Preliminary report: cultivation of mesoblastic tumours and normal tissue and notes on methods of cultivation. Am J Cancer 27:45-76

27. Halban PA, Wollheim CB, Blondel B, Renold AE (1980) Longterm exposure of isolated pancreatic islets to mannoheptulose: evidence for insulin degradation in the B cell. Biochem Pharmacol 29: $2625-2633$

28. Hellman B, Sehlin J, Täljedal I-B (1971) Transport of $\alpha$-aminoisobutyric acid in mammalian pancreatic $\beta$-cells. Diabetologia 7: $256-265$
29. Krebs HA, Henseleit K (1932) Untersuchungen über die Harnstoffbildung im Tierkörper. Hoppe-Seylers Z Physiol Chem 210: 33-66

30. Andersson A (1974) Long-term effects of glucose on insulin release and glucose oxidation by mouse pancreatic islets maintained in tissue culture. Biochem J 140:377-382

31. Swenne I (1983) Effects of aging on the regenerative capacity of the pancreatic B-cell of the rat. Diabetes 32:14-19

32. Swenne I (1984) The cell cycle and growth regulation of pancreatic B-cells. In: Lamer J, Pohl S (eds) Methods in diabetes research. Laboratory methods, part B, vol 1. John Wiley, New York, pp 175-191

33. Edén S (1979) Age- and sex-related differences in episodic growth hormone secretion in the rat. Endocrinology 105: 555-560

34. Shin SH (1982) Detailed examination of episodic bursts of $\mathrm{rGH}$ secretion by high frequency blood sampling in normal male rats. Life Sci 31: 579-602

35. Clark RG, Carlsson LMS, Robinson ICAF (1987) Growth hormone secretory profiles in conscious female rats. $\mathbf{J}$ Endocrinol 114: $399-407$

36. Nielsen JH (1982) Effects of growth hormone, prolactin, and placental lactogen on insulin content and release, and deoxyribonucleic acid synthesis in cultured pancreatic islets. Endocrinology 110: 600-605

37. Andersson I, Billig H, Fryklund L, Hansson H-A, Isaksson O, Isgaard J, Nilsson A, Rozell B, Skottner A, Stemme S (1986) Localization of IGF-I in adult rats. Immunohistochemical studies. Acta Physiol Scand 126: 311-312

38. Brown AL, Graham DE, Nissley SP, Hill DJ, Strain AJ, Rechler MM (1986) Developmental regulation of insulin-like growth factor II mRNA in different rat tissues. J Biol Chem 261: 13144-13150

39. Davidson MB (1987) Effect of growth hormone on carbohydrate and lipid metabolism. Endocrine Rev 8: 115-131

40. Hellman B, Sehlin J, Täljedal I-B (1971) Uptake of alanine, arginine, and leucine by mammalian pancreatic B-cells. Endocrinology 89: 1432-1439

41. Hellman B, Sehlin J, Täljedal I-B (1971) Stereospecific glucose uptake by pancreatic B-cells. Horm Metab Res 3: 219-220

42. Hellman B, Sehlin J, Täljedal I-B (1971) Evidence for mediated transport of glucose in mammalian pancreatic B-cells. Biochim Biophys Acta 241: 147-154

43. Hellman B, Sehlin J, Täljedal I-B (1972) Transport of L-leucine and D-leucine into pancreatic B-cells with reference to the mechanisms of amino-induced insulin release. Biochim Biophys Acta 266: 436-443

44. Whittaker PG, Taylor KW (1980) Direct effect of rat growth hormone on rat islets of Langerhans in tissue culture. Diabetologia $18: 323-328$

45. Formby B, Ullrich A, Coussens L, Walker L, Petersen CM (1988) Growth hormone stimulates insulin gene expression in cultured human fetal pancreatic islets. Endocrinology 66: 1075-1079

46. Martin JM, Friesen H (1969) Effect of human placental lactogen on the isolated islets of Langerhans in vitro. Endocrinology 84: 619-621

47. Weir GC, Leahy JL, Bonner-Weir S (1986) Experimental reduction of B-cell mass: implications for the pathogenesis of diabetes. Diabetes Metab Rev 2: 125-161

Received: 30 September 1988

and in revised form: 20 January 1989

Dr. I. Swenne

Department of Medical Cell Biology

Biomedicum

P.O. Box 571

S-751 23 Uppsala

Sweden 